\title{
Assessing the Factors Influencing Customer Satisfaction at a Specialised Boutique Restaurant in Bangkok
}

\author{
Chun Zhang \\ Graduate School, Bangkok University, Rama 4 Road, Klong-Toey, Thailand \\ Tel: 66-203-503-500Ｅ-mail: m495059747@gmail.com \\ Dr. Paul James \\ Graduate School, Bangkok University, Rama 4 Road, Klong-Toey, Thailand \\ Tel: 66-203-503-500Ｅ-mail: paul.j@bu.ac.th
}

Received: September 3, 2020 Accepted: October 20, 2020 Published: November 7, 2020

doi:10.5296/ber.v10i4.17924

URL: https://doi.org/10.5296/ber.v10i4.17924

\begin{abstract}
This paper evaluates the effects of associated factors (Quality, Service, and Environmental) that influence customer satisfaction at a single, stand-alone boutique restaurant. It uses ACSI as a research model to study customer satisfaction.

This research uses a defined population of 4800 restaurant visitors over, for 60 days representing a previous, specific, and focused marketing exercise. The calculated sample size was 369, where respondents were chosen using systematic random sampling.

Data analysis is conducted using appropriate tests that are applied to 4 variables determined as Customer Expectation, Perceived Quality, Perceived Value, and customer satisfaction extracted from the ACSI index.

The study result shows that females are the target purchase group. Environmental factors respond primarily to Customer expectation and Perceived Quality; Quality and Environmental factors respond mostly to Perceived Value, Perceived Quality, Service factors that influence Customer Satisfaction. From this study, Perceived Quality and Perceived Value are significantly positive for customer satisfaction, but Customer expectation does not positively affect customer satisfaction.
\end{abstract}


The results further indicate that customers focus on the experience, the authentic experience achieved expectation, and overall feeling after product and service experience. The results support the ACSI theory. The assessment revealed that Quality and Service factors relating to Customer Expectation and Perceived Quality factors relating to Perceived Value need to facilitate, as it can improve overall customer satisfaction for small restaurants.

Keywords: Restaurant, ASCI, Customer satisfaction, Perceived Quality, Perceived Value

\section{Introduction}

With the development of society, the emergence of restaurants and technology was inevitable (Beaugé, 2012). Many researchers believed that the fast-food industry developed from McDonald's (Ritzer, 2000) from the mid-20th Century. According to the hierarchy of needs theory (Jerome, 2013), when the economy develops to the basic needs of people, there will be higher levels of demand. Simple fast food has been unable to meet people's needs, health, nutrition, and fast have become a new demand for restaurants. Boutique restaurants show the vitality of many cuisines, different cooking methods to meet the needs of consumers at different times. Food culture's dishes are base on the differences in climate, geography, history, products, and dietary customs (McWilliams, 2007). Themed restaurants in Bangkok are trendy but lack the necessary research engagement to understand customer perceptions and their satisfaction levels for the provision and services provided. In this respect, much work is need to ensure that the management of themed restaurants operates appropriately towards heightening and differentiating characteristics and the levels of customer satisfaction (Kivela, Inbakaran and Reece, 1999).

\section{Literature Review}

For companies, customers are considered essential intangible assets (Sacui and Dumitru, 2013), and gaining customer satisfaction is essential for all companies (Rust and Oliver, 1994). To satisfy customers is not only an essential way for modern restaurants to earn a profit and occupy the market but also an essential means for restaurants to improve their operating conditions and further enhance their core competitiveness (Bitran and Pedrosa 1998). Understanding customer satisfaction may help small restaurants build an essential role in development and even survive. In research, questions and assumptions are mostly used by researchers to shape and specifically and focus research purposes (Creswell, 2003). Consumer satisfaction about boutique restaurants has an essential impact on the restaurant.

Customer satisfaction relies on some attributes/facets that are associated/underpinned with elements such as Customer Expectations; Perceived Quality, and Perceived Value. These will be the focus of this research orientation and are further discuss below:

\subsubsection{Customer Expectation}

Customer expectations are those aspects of service that lead to a personal service-buyer decision relating to the expectancy disconfirmation paradigm (Oh, 1999). The relationship to customer satisfaction was first researched by Oliver (1981), when experiencing a purchase decision or encounter. For example, when an adverse reaction to a purchasing meeting occurs, 
negative disconfirmation occurs (Pizam and Milman, 1993). When the purchase encounter meets or exceeds the customer expectations, positive disconfirmation occurs (Cardello and Sawyer, 1992).

\subsubsection{Perceived Quality}

Customer perceived service quality is seen by many researchers as reflecting food quality and restaurant atmospherics characterized as cognitive evaluations by customers that generate suitable and specific affective responses (Prayag, Khoo-Lattimore and Sitruk, 2015). Further, perceived Quality is also recognition as indicating the level of Quality of restaurants in terms of customer perceptions of Value (Iglesias and Guillen, 2004).

\subsubsection{Perceived Value}

Perceived Value is a measure of the Quality of experience with the price or perceived cost after consumption (Suryad et al., 2018). Services and products in restaurants lead to "promises of satisfaction" (Levitt, 1983).

To improve consumers' satisfaction with services, products, and the environment, independent research of customer satisfaction would help focus management orientation in restaurants (Todorov and Smallbone, 2014). Particular boutique restaurants, as it has not been well research (Alam, 2002). However, literature related to understanding customer satisfaction about themed restaurants remain sparse (James and Murnan, 2004).

\subsection{American Customer Satisfaction Index (ACSI)}

Measuring customer satisfaction requires research focused on assessing characteristics associated with customer perceptions. However, these characteristics are not simple to evaluate, and there are many models related to their assessment. In this research, the ASCI methodology is utilized, which was first created by (Fornell, 1992). It makes good sense to assess its development and application.

ACSI is a macro indicator that measures the Quality of economic output. It is a comprehensive evaluation indicator of customer satisfaction in the process of consumption of products and services. ACSI is the complete system and the best application effect and theoretical model for a country's customer satisfaction. ACSI is a customer satisfaction index model established by Fornell (1992). The establishment of the ACSI model is bass on the Swedish Customer Satisfaction Index Model (SCSB) (Johnson et al., 2001). It scientifically utilizes the consumer cognitive process and puts the overall satisfaction degree into a causal interaction system that interacts and interacts with each other. The model can help explain the relationship between the consumption process and overall satisfaction (Tsiotsou and Wirtz, 2015), and can indicate the consequences of satisfaction (Bolton and Lemon, 1999), thus giving the overall satisfaction toward expectation characteristics (Boulding et al., 1993). The comprehensive customer satisfaction model is bass on the knowledge of the entire customer experience (Bassi and Guido, 2006). This model links these relationships by analyzing the connections between customers and businesses in all aspects of products and services (Engel, Blackwell, and Miniard, 1993). This model provides practical decision support for companies 


\section{Macrothink}

Business and Economic Research ISSN 2162-4860 2020, Vol. 10, No. 4

to improve customer satisfaction, effectively improve product and service quality, enhance brand image and customer loyalty, and use this model to obtain effective methods, so it has also achieved good results. It is an excellent way to explore ways for companies to improve their competitiveness (Lu Shuai 2011). Consequently, customer satisfaction research studies factors that may affect customer satisfaction, such as products, services, environment, brand awareness, product selection, and brand image (Solomon and Lowrey, 2018).

\section{Conceptual Model}

Customer satisfaction relies on some facets associated/underpinned with elements such as Perceived Quality; Customer Expectations, and Perceived Value. These will be the focus of this research orientation. This is modeled below, along with the hypotheses development:

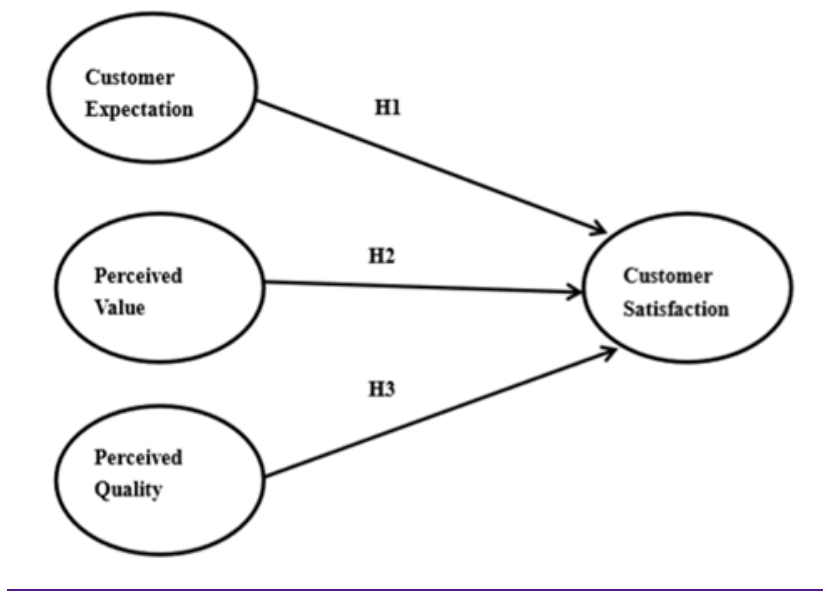

Figure 1. Conceptual Model and Hypotheses Development

Source: Edited and Extracted from The ACSI

Hypothesis statements:

H1a. Customer Expectations has a positive influence on Perceived Quality.

H1b. Customer Expectations has a positive influence on Perceived Value.

H1c. Customer Expectations has a positive influence on Customer Satisfaction.

H2a. Perceived Quality has a positive influence on Perceived Value.

H2b. Perceived Quality has a positive influence on Customer Satisfaction.

H3. Perceived Value has a positive influence on Customer Satisfaction.

\section{Methodology}

The methodology responds to a quantitative application, where the population, sampling, and questionnaire design and data outcomes are connected quantitively, tested, and shown their respective relationships, allowing generalisability. 


\subsection{Population and Sample Selection}

\subsubsection{Population Criteria}

The focus for the data used in this study was from a single, themed restaurant, A Chinese restaurant focused on Chinese Sichuan cuisine. Therefore, it minimizes deviations in sample selection and helps avoid over-representation or under-representation on a segment (Leavy, 2017), leading to an accurate reflection of the targeted population.

The target population incorrect verb form by demographic characteristics, geographic area, product usage characteristics, or service usage characteristics (McDaniel, 2007). For this study, the target population consists of members directly associated with pre-arranged travel groups from China. This population is considered a closed community, and every member can be explicitly identified from the data provided by the travel organization (Patten and Newhart, 2019). Access to the data was grant through the membership criteria and management of the travel company (Saunders, Lewis and Thornhill, 2007).

The population - $\mathrm{N}=4800$. This population was constructed from an assessment of restaurant data over 60 days and is calculate by utilizing a booking review and actual customer visitations. Thus, the population could be construe as defined solely from the targeted member groups.

\subsubsection{Sampling Methods and Sampling Regime}

The primary data is to meet the particular needs of the specific survey data (Lacobucci and Churchill, 2018). As the target population parameters are known, the probability sampling technique of simple random sampling was chosen to reduce the large population into a manageable and representative proportion (Saunders, Lewis and Thornhill, 2007).

\subsubsection{Sample Size in Research}

The probability sampling method is use; even a small fraction of the total population can provide an overall reliable measurement of the data (Zikmund, 2000). The sampling process gives a number to each individual expected to dine for all 4800 customers and then to apply the Yamane (1967) formula (McDaniel, 2007) to calculate the sample size. Using this formula resulted in a sample size of 369 .

\subsubsection{Sampling Regime}

Each respondent in the population had an equal chance to be selected. The selection process used a random number table to help select respondents. The expected response rate was around 31\% (Marković, Raspor, and Šegarić, 2010). No shows at the restaurant were recorded and noted but were considered so low as to have no affect on the expected rate of response.

\subsection{Questionnaire Design}

Through this method, a set of formal questions that get the research project (McDaniel, 2007). It plays a vital role in the data collection process. The application of a pilot study will aid in 
the reliability of the questionnaire by helping to minimize the response of unclear or misrepresentation of subsequent answers. The questionnaire used was in Chinese but had been translate into English for reporting purposes. The translation language was pre-tested as in the pilot study process (Tsang, Royse and Terkawi, 2017), as in s4.2.1 below.

The preparation of the questionnaire follows the definition of the problem and the research method in terms of the study data requirements and results from the consideration of how the questionnaire meets the requirements for editing, coding, and data processing (McDaniel, 2007).

\subsubsection{Pilot Study}

The sample size was rationalize as appropriate within the range of 10-30 respondents from the study population (Isaac and Michael, 1995; Hertzog, 2008). Consequently, a pilot study was conduct using 20 respondents from the defined population for testing the questionnaire (Hassan, Schattner, and Mazza, 2006). These individuals were not select again for the primary data collection process. This was conduct to test the questionnaire processes and the language (Lavrakas, 2008), thus minimizing translation misunderstanding because of flawed construct and item/question meaning bias (Waltz, Strickland and Lenz, 2010).

\subsubsection{Statistical Measures}

The primary purpose of statistical inference (Waltz, Strickland, and Lenz, 2010) is to use the data contained in the sample, then to estimate the population parameters and test the hypotheses - using multiple linear regressions analysis (Creswell, 2003). Statistical measures also included reliability (Cronbach's Alpha Coefficient), demographics - percentage ratio and frequency, and validity - using factor analysis.

\section{Results}

The full data set (outcome) was analyzed using SPSS, v25. The response rate that was achieve was 189 (76.6\%). This indicated that the actual response rate was higher than expected. However, this could be explain by the excellent rapport between the researcher and the respondents in a closed member restaurant setting (Dillman, 2007).

\subsection{Reliability Statistics}

The questionnaire (consisting of 23 questions) was test using Cronbach's Alpha Coefficient using SPSS, v25 - before further analysis. The statistical results obtained show that the Cronbach's Alpha Coefficient for the questionnaire was 0.849 and is considered to exhibit excellent internal consistency (Tavakol and Dennick, 2011) and is therefore accepted.

\subsection{Validity Analysis}

By examining the amount of all data in the questionnaire, the results show that KMO is 0.826 , indicating that the structural process of the questionnaire was good. The Bartlett's Test of Sphericity showed the resultant Chi-Square as 3957.12, df of 296, with Sig is 0.000, which with a significance of less than 0.05 , translates to a strong correlation and acceptance of the data as valid. 


\subsection{Descriptive Statistics}

Utilizing fundamental descriptive analysis of the personal information from the respondent. Which gives a sense of overall demographics, with the significant item presented - as in Table 1, below:

Table 1. Demographic Analysis

\begin{tabular}{|l|l|l|l|}
\hline \multicolumn{2}{|l|}{ Demographic Data (283) } & Frequency & Percent \% \\
\hline Gender & Male & 97 & $51.2 \%$ \\
\hline Age & Female & 92 & $48.8 \%$ \\
\hline Status & 25-34years old & 153 & $41.5 \%$ \\
\hline The reason to come to Bangkok & Married & 222 & $60.2 \%$ \\
\hline Education & Travel/Leasure & 137 & $37.1 \%$ \\
\hline Income & Bachelor's Degree & 151 & $40.9 \%$ \\
\hline Occupation & 30,001-40,000 baht. & 110 & $29.8 \%$ \\
\hline & Private employee & 135 & $36.6 \%$ \\
\hline
\end{tabular}

This suggested that most respondents were male, the largest segment by age was 25-34 years old, married, had a bachelor's degree, earned up to $40000 \mathrm{baht} / \mathrm{month}$, and worked in private companies.

\subsection{Factor Analysis}

Seven factors were obtain after the questionnaire was rotate. The minimum acceptability of the factor load was 0.35 . The data ranged from 0.650 to 0.867 , which indicated that the questionnaire had a high structural validity.

The first variable is the decisive factor, and six elements are also determined by the rotation of the load, which is consistent with the structural variables of the selected model.

\subsection{Correlations}

According to the correlation analysis, the following table is a significant result showing and deleting duplicate items and remove non-hypothetical questions. This is viewed in Table 2, below.

Table 2. Correlation Matrix

\begin{tabular}{|l|l|l|l|}
\hline & Perceived Quality & Perceived Value & Customer Satisfaction \\
\hline Customer Expectations & I & + & + \\
\hline Perceived Quality & & + & + \\
\hline Perceived Value & & & + \\
\hline
\end{tabular}


5.6 Simple Linear Regression Analysis

The Simple Linear Regression Analysis result is stated in Table 3, below:

Table 3. Simple Linear Regression Analysis Outcomes

\begin{tabular}{|l|l|l|l|}
\hline & Hypotheses & Sig. & Status \\
\hline H1a & Customer Expectations has a positive impact on Perceived Quality & 0.821 & Rejected \\
\hline H1b & Customer Expectations has a positive impact on Perceived Value & 0.763 & Accepted \\
\hline H1c & $\begin{array}{l}\text { Customer Expectations has a positive impact on Customer } \\
\text { Satisfaction }\end{array}$ & 0.814 & Accepted \\
\hline H2a & Perceived Quality has a positive impact on Perceived Value & 0.747 & Accepted \\
\hline H2b & Perceived Quality has a positive impact on Customer Satisfaction & 0.759 & Accepted \\
\hline H3 & Perceived Value has a positive impact on Customer Satisfaction & 0.856 & Accepted \\
\hline
\end{tabular}

The results allow the status to resolved as determined in Table 3, above.

\subsection{Determination of Model Results}

According to the above analysis and outcomes of the study data, it would appear to prove that the hypothesis: H1a through the correlation analysis and regression analysis is reject, as Customer Expectations are positively correlated with Perceived Quality and are not supported. However, all other hypotheses are accepted.

The results showed the hypothesis outcomes as (1) Customer Expectations had no substantial impact to Perceived Quality; (2) Customer Expectations had a substantial impact on Perceived Value; (3) Customer Expectations had a substantial impact on Customer Satisfaction; (4) Perceived Quality had a substantial impact on Perceived Value; (5) Perceived Quality had a substantial impact on Customer Satisfaction and also on Perceived Value; and (6) Perceived Value had a substantial impact on Customer Satisfaction.

The outcome indicates that Customer Expectations and Perceived Value are the main influencing factors on Customer Satisfaction, as demonstrated through the applied correlation and regression analysis. This is consistent with the findings contained in previous studies (Bitner and Hubbert, 1994; Zeithaml, Berry, and Parasuraman, 1996). Therefore, in restaurant advertising and marketing, these marketing practices should reflect this research by reinforcing an appropriate message consistently (Mills and Thomas, 2008), targeted towards showing enhanced engagement in facets of service and physical features of the restaurant that they will be interested in and expect (Susskind and Chan, 2000). Only by making realistic commitments to consumers can restaurant management assess the real impacts of Customer Expectations and Perceive Value on the restaurant service/product package (Genestre and Herbig, 1996) and deliver appropriately what their customers want.

Further, utilizing word-of-mouth communication through informal interpersonal electronic communication helps restaurants engage closely with members and customers (Lee, 2011). This communication channel helps counter negative issues associated with Perceived Value and Perceived Quality. Restaurants, therefore, need to guide word-of-mouth communication 
to play a positive role for customers, where restaurants deal with customer complaints, and eliminate misleading advertising, build better customer communication channels (Berry et al., 2014). Applying this would lead to more loyal customers (Royo-Vela and Casamassima, 2011).

The analysis further suggests that the environmental impacts on customer expectations are crucial to providing repeat customers (El-Adly and Eid, 2016), leading to greater customer loyalty (Fowler, 2003).

\section{Conclusions}

In this paper, the ACSI model was used to study the factors related to customer satisfaction at a themed restaurant. While raising the prospect that quality/environmental factors have an impact on perceived Value, then this has implications for service developments (Gupta, McLaughlin, and Gomez, 2007), and perceived Quality (McDougall, and Levesque, 2000). Consequently, customer satisfaction does not have one, a factor that overrides any other aspect (Grönroos, 2007). In this way, customer satisfaction at the restaurant is, therefore, continually masked by the interaction of these studied factors (Gummesson, 1999). They are essential in themselves and provide a way for the restaurant management to assess and apply/develop marketing strategies to engage customers towards consistently meeting customer satisfaction requirements (Kim, 2009). However, in practice, focusing on each factor would also provide the opportunity to clarify different customer attributes and needs, which for a small restaurant may be enhanced through more creative methods of customer engagement (Sim, Mak, and Jones, 2006) and more improved CRM practices (Nguyen, 2012).

\section{Reference}

Alam, I. (2002). An Exploratory Investigation of User Involvement in New Service Development. Academy of Marketing Journal, 30(3), 250-261.

https://doi.org/10.1177/0092070302303006

Bassi, F., \& Guido, G. (2006). Measuring customer satisfaction: From product performance to consumption experience. Journal of Consumer Satisfaction, Dissatisfaction, and Complaining Behavior, 19, 76-89.

Beaugé, B. (2012). On the idea of novelty in cuisine: A brief historical insight. International Journal of Gastronomy and Food Science, 1(1), 5-14.

https://doi.org/10.1016/j.ijgfs.2011.11.007

Berry, R., Tanford, S., Montgomery, R., \& Green, A. (2014). How We Complain: The Effect of Personality on Consumer Complaint Channels. Journal of Hospitality \& Tourism Research, 42(1), 74-101. https://doi.org/10.1177/1096348014550921

Bitner, M., \& Hubbert, A. (1994). Encounter satisfaction versus overall satisfaction versus quality. In R. Rust, \& R. Oliver (Eds.), Service quality: New direction in theory and practice. Sage Publications: New York, NY, US. 
Bitran, G., \& Pedrosa, L. (1998). A Structured Product Development Perspective for Service Operations. European Management Journal, 16(2), 169-189.

https://doi.org/10.1016/S0263-2373(97)00086-8

Bolton, R., \& Lemon, K. (1999). A dynamic model of customers' usage of services: Usage as an antecedent and consequence of satisfaction. Journal of Marketing Research, 36(2), 171-186. https://doi.org/10.2307/3152091

Boulding, W., Kalia, A., Staelin, R., \& Zeithaml V. (1993). A dynamic process model of service quality: From expectations to behavioral intentions. Journal of Marketing Research, 30(1), 7-27. https://doi.org/10.2307/3172510

Cardello, A., \& Sawyer, F. (1992). Effects of Disconfirmed Consumer Expectations on Food Acceptability. Journal of Sensory Studies, 7(4), 253-277.

https://doi.org/10.1111/j.1745-459X.1992.tb00194.x

Creswell, J. (2003). Research Design: qualitative, quantitative, and mixed-method approaches. Sage Publications: Thousand Oaks, CA.

Dillman, D. (2007). Mail and Internet surveys: The tailored design method. Wiley: Hoboken, NJ.

El-Adly, M., \& Eid, R. (2016). An empirical study of the relationship between shopping environment, customer perceived value, satisfaction, and loyalty in the UAE malls context. Journal of Retailing and Consumer Services, 31, 217-227.

https://doi.org/10.1016/j.jretconser.2016.04.002

Engel, J., Blackwell, R., \& Miniard, P. (1993). Consumer Behavior. Dryden Press: Fort Worth, TX.

Fornell, C. (1992). National customer satisfaction Barometer: The Swedish Experience. Journal of Marketing, 56(1), 6-12. https://doi.org/10.1177/002224299205600103

Fowler, M. (2003). Fifteen critical success factors for real-time customer loyalty. Restaurant Hospitality, 87(8), 60-64.

Genestre, A., \& Herbig, P. (1996). Service expectations and perceptions revisited: adding product quality to SERVQUAL. Journal of Marketing Theory and Practice, 4(4), 72e82. https://doi.org/10.1080/10696679.1996.11501740

Grönroos, C. (2007). Service management and marketing. John Wiley \& Sons: London.

Gummesson, E. (1999). Total Relationship Marketing. Butterworth-Heinemann: Oxford.

Gupta, S., McLaughlin, E., \& Gomez, M. (2007). Guest satisfaction and restaurant performance. Cornell Hotel and Restaurant Administration Quarterly, 48(3), 284-298. https://doi.org/10.1177/0010880407301735

Hassan, Z., Schattner, P., \& Mazza, D. (2006). Doing A Pilot Study: Why Is It Essential? Malaysian Family Physician, 1(2-3), 70-73. 


\section{Macrothink

Hertzog, M. (2008). Considerations in determining sample size for pilot studies. Research in Nursing \& Health, 31(2), 180-191. https://doi.org/10.1002/nur.20247

Iglesias, M., \& Guillén, M. (2004). Perceived quality and price: their impact on the satisfaction of restaurant customers. International Journal of Contemporary Hospitality Management, 16(6), 373-379. https://doi.org/10.1108/09596110410550824

Isaac, S., \& Michael, W. B. (1995). Handbook in research and evaluation. Educational and Industrial Testing Services: San Diego, CA, US.

Jerome, N. (2013). Application of Maslow's hierarchy of need theory; impacts and implications on organizational culture, human resource, and employee's performance. International Journal of Business and Management Invention, 2(3), 39-45.

Johnson, M., Gustafsson, A., Andreassen, T., Lervik, L., \& Cha, J. (2001). The evolution and future of national customer satisfaction index models. Journal of Economic Psychology, 22(2), 217-245. https://doi.org/10.1016/S0167-4870(01)00030-7

Kim, W. (2009). Customers' Responses to Customer Orientation of Service Employees in Full-Service Restaurants: A Relational Benefits Perspective. Journal of Quality Assurance in Hospitality \& Tourism, 10(3), 153-174. https://doi.org/10.1080/15280080902988188

Kivela, J., Inbakaran, R., \& Reece, J. (1999). Consumer research in the restaurant environment, part 1: A conceptual model of dining satisfaction and return patronage. International Journal of Contemporary Hospitality Management, 11(5), 205-222.

https://doi.org/10.1108/09596119910272739

Iacobucci, D., \& Churchill, A. (2018). Market Research Methodological Foundation. Early-Lite Books: TN, US.

Lavrakas, P. (2008). Encyclopedia of survey research methods. Sage Publications: Thousand Oaks, CA. https://doi.org/10.4135/9781412963947

Leavy, P. (2017). Quantitative, Qualitative, Mixed Methods, Arts-Based, and Community-Based Participatory Research Approaches. The Guilford Press: London.

Lee, M., Shi, N., Cheung, C., Lim, K., Sia, C. (2011). Consumer's decision to shop online: the moderating role of positive informational social influence. Information \& Management, 48(6), 185-191. https://doi.org/10.1016/j.im.2010.08.005

Levitt, T. (1983), The Marketing Imagination. The Free Press: New York, NY, US.

Liu, X. (2005). Customer Satisfaction Management. China Science and technology information, 12, 39-40.

Marković, S., Raspor, S., \& Šegarić, K. (2010). Does Restaurant Performance Meet Customers' Expectations? An Assessment of Restaurant Service Quality Using A Modified Dineserv Approach. Tourism and Hospitality Management, 16(2), 181-195.

McDougall, G., \& Levesque, T. (2000). Customer satisfaction with services: putting 
perceived value into the equation. Journal of Services Marketing, 14(5), 392-410. https://doi.org/10.1108/08876040010340937

McDanniel, C., \& Gates, R. (2007). Marketing Research. John Wiley \& Sons: Hoboken, NJ.

McWilliams, M. (2007). Food Around the World: A Cultural Perspective. Pearson Education: New Delhi.

Mills, J., \& Thomas, L. (2008). Assessing Customer Expectations of Information Provided On Restaurant Menus: A Confirmatory Factor Analysis Approach. Journal of Hospitality \& Tourism Research, 32(1), 62-88. https://doi.org/10.1177/1096348007309569

Nguyen, B. (2012). The dark side of customer relationship management: Exploring the underlying reasons for pitfalls, exploitation, and unfairness. Journal of Database Marketing \& Customer Strategy Management, 19(1), 56-70. https://doi.org/10.1057/dbm.2012.5

Oh, H. (1999). Service quality, customer satisfaction, and customer value: A holistic perspective. International Journal of Hospitality Management, 18(1), 67-82.

https://doi.org/10.1016/S0278-4319(98)00047-4

Oliver, R. (1981). Measurement and evaluation of satisfaction processes in retail settings. Journal of Retailing, 57(3), 25-48.

Patten, M., \& Newhart, M. (2019). Understanding Research Methods: An Overview of the Essentials. Routledge: Abingdon.

Pizam, A., \& Milman, A. (1993). Predicting satisfaction among first-time visitors to a destination by using the expectancy disconfirmation theory. International Journal of Hospitality Management, 12(2), 197-209. https://doi.org/10.1016/0278-4319(93)90010-7

Prayag, G., Khoo-Lattimore, C., \& Sitruk, J. (2015). Casual Dining on the French Riviera: Examining the Relationship Between Visitors' Perceived Quality, Positive Emotions, and Behavioral Intentions. Journal of Hospitality Marketing \& Management, 24(1), 24-46.

https://doi.org/10.1080/19368623.2014.859114

Ritzer, G. (2000). An Introduction to McDonaldization. In: The McDonaldization of Society, Pine Forge Press: Thousand Oaks, CA.

Royo-Vela, M., \& Casamassima, P. (2011). The influence of belonging to virtual brand communities on consumers' affective commitment, satisfaction, and word-of-mouth advertising: the ZARA case. Online Information Review, 35(4), 517-542.

https://doi.org/10.1108/14684521111161918

Rust, R., \& Oliver, R. (1994). Service quality: Insights and managerial implications from the frontier. Sage: Thousand Oaks, CA.

Sacui, V., \& Dumitru, F. (2013). Market-based assets. Building value through marketing investments. Procedia - Social and Behavioral Sciences, 124(2014), 157-164.

https://doi.org/10.1016/j.sbspro.2014.02.472 


\section{Macrothink}

Business and Economic Research ISSN 2162-4860 2020, Vol. 10, No. 4

Saunders, M., Lewis, P., \& Thornhill, A. (2007). Research Methods for Business Students. Prentice-Hall: Harlow.

Sim, J., Mak, B., \& Jones, D. (2006). A Model of Customer Satisfaction and Retention for Hotels. Journal of Quality Assurance in Hospitality \& Tourism, 7(3), 1-23. https://doi.org/10.1300/J162v07n03_01

Solomon, M., \& Lowrey, T. (2018). The Routledge Companion to Consumer Behavior. Routledge: Abingdon. https://doi.org/10.4324/9781315526935

Suryad, N., \& Suryana, Y., \& Knomalande, R., \& Sari, D. (2018). Consumer, customer, and perceived value past and Present. Academy of strategic management journal, 17(4).

Susskind, A., \& Chan, E. (2000). How restaurant features affect check averages: A study of the Toronto restaurant market. The Cornell Hotel and Restaurant Administration Quarterly, 41(6), 56-63. https://doi.org/10.1177/001088040004100608

Tavakol, M., \& Dennick, R. (2011) Making Sense of Cronbach's Alpha. International Journal of Medical Education, 2, 53-55. https://dx.doi.org/10.5116\%2Fijme.4dfb.8dfd

Todorov, K., \& Smallbone, D. (2014). Handbook of Research on Strategic Management in Small and Medium Enterprises. Business Science Reference: Hershey, PA.

https://doi.org/10.4018/978-1-4666-5962-9

Tsang, S., Royse, C., \& Terkawi, A. (2017). Guidelines for developing, translating, and validating a questionnaire in perioperative and pain medicine. Saudi Journal of Anaesthesia, 11(Suppl 1), S80-S89. https://dx.doi.org/10.4103/sja.SJA_203_17

Tsiotsou, R., \& Wirtz, J. (2015). The Three-Stage Model of Service Consumption. In J. Bryson \& P. Daniels (Eds.), The Handbook of Service Business: Management, Marketing, Innovation, and Interdenominational (pp. 105-128). Chapter: 7. Edward Elgar: Cheltenham. https://doi.org/10.4337/9781781000410.00015

Waltz, C., Strickland, O., \& Lenz, E. (2010). Measurement in nursing and health research. Springer: New York, NY.

Zeithaml, V., Berry, L., \& Parasuraman, A. (1996). The behavioral consequences of service quality. The Journal of Marketing, 60(2), 31-46. https://dx.doi.org/10.2307/1251929

Zikmund, G., Babin, B., Carr, J., \& Griffin, M. (2013). Business Research Methods. South-Western CENGAGE Learning: Mason, $\mathrm{OH}$.

\section{Copyright Disclaimer}

Copyright for this article is retained by the author(s), with first publication rights granted to the journal.

This is an open-access article distributed under the terms and conditions of the Creative Commons Attribution license (http://creativecommons.org/licenses/by/4.0/). 